\title{
Induction Therapy in Renal Transplant Recipients
}

\author{
Cheguevara Afaneh, Meredith J. Aull, Sandip Kapur and David B. Leeser \\ Department of Surgery, Division of Transplant Surgery \\ New York-Presbyterian Hospital-Weill Cornell Medical College, New York, NY
}

USA

\section{Introduction}

\subsection{Historical overview}

Renal transplantation remains the most effective treatment modality for end-stage renal disease. The initial results with renal transplantation were plagued with significant perioperative morbidity and high rates of immunological events. At the time, the transplant physician's armamentarium consisted of glucocorticoids and azathioprine. As modifications and improvements in surgical technique reduced morbidity, immunological events remained formidable foes to the transplant physician. Significant efforts were undertaken to elucidate the components and mechanisms of these immunological events, ultimately leading to the discovery of lymphocytes as the primary culprits in acute rejection. Early preclinical trials demonstrated that lymphocyte-specific antibodies could be induced in animal models by injecting them with lymphocytes. The serum could then be isolated and re-injected in other animals to decrease the lymphocyte count. Thus, these experiments lead to the earliest forms of antilymphocyte antibody formulations, including antithymocyte globulin, antilymphocyte serum, and antilymphocyte globulin (Bishop et al., 1975; Cosimi et al., 1976). These initial medications had little specificity and broad effects, but their potent ability to treat acute rejection episodes led to their widespread use in the 1970's (Cosimi, 1981a).

The extensive use of these formulations exposed their various drawbacks. Because of nonspecific binding, cross-reactivity with various hematopoietic cells revealed dose-limiting side effects including thrombocytopenia, anemia, and neutropenia (Henricsson et al., 1977; Rosenberg, 1975). Additionally, the method of preparation was not standardized, thus leading to dosing variations. Because these formulations were typically made in rabbits or horses, the proteins had potential antigenic properties leading to the development of serum sickness, cytokine release syndrome, or even anaphylaxis (Niblack et al., 1987; Prin Mathieu et al., 1997; Tatum et al., 1984).

The development of specific, monoclonal antibodies by Kohler and Milstein circumvented many of the drawbacks of polyclonal formulations, including lack of specificity and variability in preparation (Kohler \& Milstein, 1975). Muromonab, or OKT3, was the first monoclonal antibody prepared from mouse, which is specific for cluster of differentiation 3 (CD3) (Cosimi et al, 1981b). OKT3 was effective at specifically depleting $\mathrm{T}$ cells from the 
circulation, and became widely used as a valuable tool to combat acute rejection episodes (Ortho Multicenter Transplant Study Group, 1985; Ponticelli et al., 1987). Nevertheless, these monoclonal formulations still maintained some of the similar side effect profile of the polyclonal formulations, including cytokine release syndrome and human antigenic response to animal proteins, which lead to limited dosing in some patients (Jaffers et al., 1986).

The 1980's marked an important era in transplantation with new advances in genetic engineering. Monoclonal antibodies became more sophisticated, targeting specific $\mathrm{T}$ cell populations and allowing blockade of $\mathrm{T}$ cell activation, such as the interleukin-2 receptor (IL-2R) or CD25 (Vincenti et al., 1997). Moreover, the ability to avoid antigenic proteins by encoding genetic sequences of DNA binding sites of animal proteins onto human antibodies led to the development of chimeric monoclonal antibodies (Boulianne et al., 1984; Jones et al., 1986; Morrison et al., 1984). Using these techniques, soluble fusion proteins can be formed by merging nonantibody receptors with the Fc portion of antibodies.

\subsection{Antibodies}

Comprehension of the structure and function of antibodies is critical to understanding the efficacy of antibody induction therapy. Antibodies are composed of two identical heavy chains (either $\mu, \gamma, \alpha, \varepsilon$, or $\delta$ ) and two identical light chains (either $\mathrm{k}$ or $\lambda$ ). The heavy and light chain portions create two identical antigen binding sites (Fab fragment) which are held together by the common region, termed the Fc portion (Capra \& Edmundson, 1977). The type of heavy chain differentiates the immunoglobulin type as IgM, IgG, IgA, IgE, and IgD. In clinical transplantation, the IgG molecule is typically utilized, as it's readily produced and structurally feasible to manipulate with ease (Fig. 1).

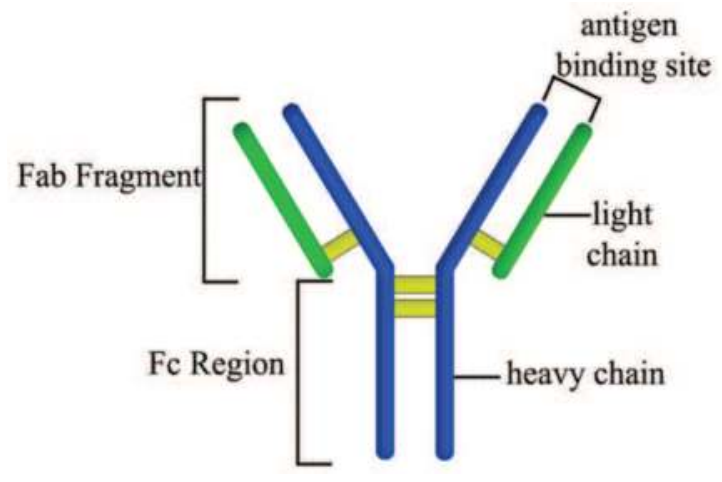

Fig. 1. Basic antibody structure. Depicted is a standard IgG molecule. The heavy chains are colored in blue, while the light chains are colored in green. The yellow lines signify the disulfide bonds

Antibodies are present on the surface of B cells. Upon secretion into the serum, antibodies are able to neutralize circulating antigens. Antibodies maintain their effector functions irrespective of species, which make them useful in early studies of antibody therapies in transplantation. Antibodies are capable of various functions, including mimicking activating ligands of receptors and serving as receptor inhibitors by blocking the ligand binding site 
(Tite et al., 1986; Wong et al., 1990). In some instances, antibody binding can lead to both activation and inhibition by inducing surface molecule internalization, whereby the molecule is removed from the surface of the cell (Kerr \& Atkins, 1989). This results in a negligible net effect. A major limitation of antibody use is the inability to directly bind intracellular molecules.

Antibodies have the ability to deplete target cells through two fundamental mechanisms. First, antibodies have the capability to activate the complement system resulting in complement-mediated lysis of target cells. Second, certain cells with Fc region receptors have the ability to phagocytose cells covered with antibodies through a mechanism termed antibody-dependent cellular cytotoxicity (ADCC)(Fig.2). The efficacy with which this occurs depends upon the Fab fragment and the Fc region (Ferrant et al., 2004). It is important to note that cells which have significantly matured, or memory cells, are somewhat resistant to antibody-dependent depletion mechanisms, possibly due to increased expression of antiapoptotic or complement regulatory genes (Pearl et al, 2005).

The vast properties of antibodies make them suitable for therapeutic indications. Nevertheless, even minor changes in antibody structure can significantly alter function. Additionally, the interplay of the complement system and ADCC properties further complicates the predicted function of various antibody-depleting therapies.

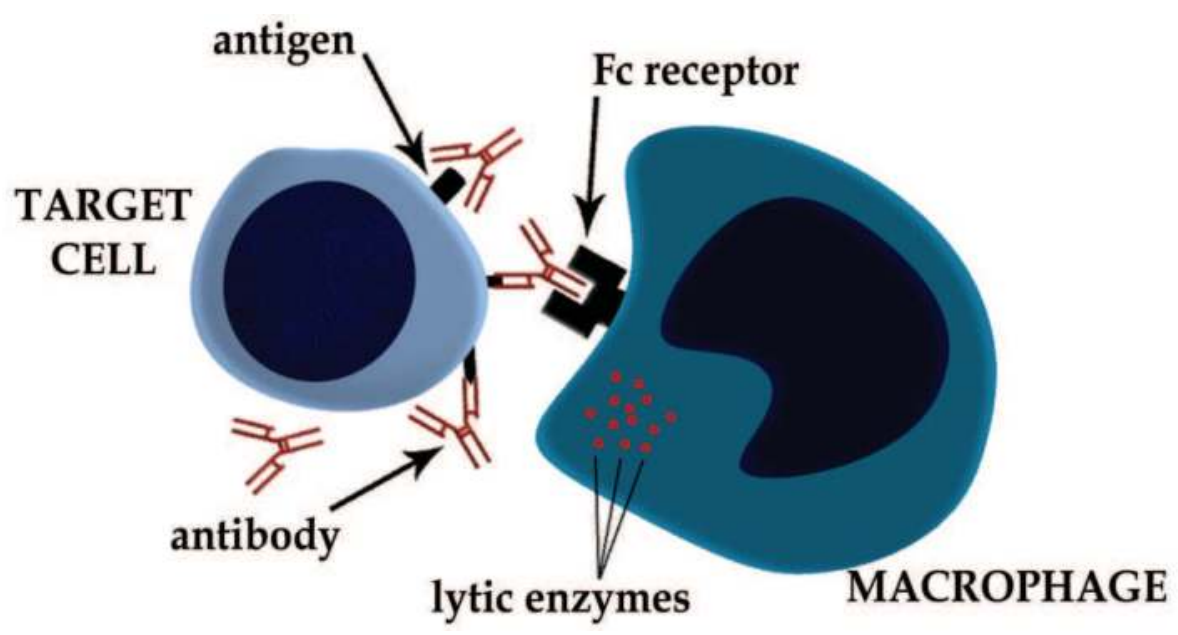

Fig. 2. Antibody-dependent cellular cytotoxicity (ADCC). The Fc receptor on the machrophage is used to bind the constant Fc portion of antibodies to facilitate engulfment of cells coated with antibodies

\subsection{Clinical classification of induction agents}

Induction immunosuppressive medications can be classified into two groups: depleting agents and non-depleting agents. The categorization is based on the ability of the medication to target specific antigens or cells, leading to a decrease in the total expression or cell count. Most depleting agents are relatively potent with potential for toxicity with prolonged administration. Non-depleting agents are generally well-tolerated. Depleting agents are also used for severe or refractory cases of acute rejection and have proven to be 
more effective than glucocorticoids in treating episodes of acute rejection (Webster et al., 2006). In addition, the use of induction agents has decreased the rates of acute rejection in the first 6 months compared to no induction therapy (Szczech et al., 1997). Although these short-term benefits appear promising, long-term outcomes, including patient and graft survival rates, have not been shown to be altered by the use of induction therapy. This is possibly related to the effects of long-term maintenance immunosuppressive therapy or patient co-morbidities.

The overall success of a transplanted renal allograft is contingent on both surgical prowess and the use of potent immunosuppressive medications. Although induction therapy has not affected surgical morbidity, the rate of allograft thrombosis has been shown to be reduced in children with the use of induction agents (Humar et al., 2001; Singh et al., 1997). However, not all medications used are FDA-approved for induction therapy. Moreover, it is important to note that these medications are not without definite risks, including serious infectious complications and the development of post-transplant lymphoproliferative disorder (PTLD), which has been well-described with the use of OKT3 and maintenance immunosuppression (Bustami et al., 2004; Jamil et al., 1999). Because of the effects of depleting agents on T cells, appropriate prophylactic therapies should be administered to all transplant recipients. Duration of therapy is typically contingent on the donor and recipient immunological history. Thus, tailoring the immunosuppressive regimen to each patient is critical to avoiding complications.

In 1995 induction therapy was used in less than half of all kidney transplants in the United States, while 10 years later, approximately $70 \%$ of all kidney transplant recipients received induction therapy (Meier-Kriesche et al., 2006). Given the availability of various potent, specific induction agents in modern transplantation, the clinical dilemma lies in selecting the most appropriate agent for a given patient, taking into account co-morbidities, donor quality, immunological status, and planned maintenance therapy.

\section{Depleting agents}

\subsection{Antithymocyte globulin}

\subsubsection{Mechanism}

Various polyclonal depleting agents are available; however, this discussion will focus on rabbit antithymocyte globulin (rATG). In rATG, the polyclonal heterologous antibody formulation is produced from immunizing rabbits with human thymocytes, which serve as the immunogens (Fig. 3) (Hardinger, 2006). The rabbit serum is then gathered and purified to remove antibodies with potentially detrimental effects and only the IgG isotypes are collected. Despite these purification techniques, it is possible that the majority of antibodies in these formulations serve no therapeutic purpose (Bonnefoy-Berard et al., 1991). When administered to humans, the rATG antibody formulations bind all antigens that the rabbits were exposed to during the immunization process.

Rabbit ATG binds multiple $\mathrm{T}$ cell surface antigens and receptors involved in antigen recognition, adhesion and costimulation. These include CD2, CD3, CD4, CD5, CD8, CD28, CD45, and CD40L. In addition, rATG may also bind non-T cell molecules such as CD16, CD20, CD56, and the major histocompatibility molecules (class I and II) (Bonnefoy-Berard et al., 1991; Hardinger, 2006). The depleting effect of rATG occurs within 24 hours of administration and can persist with a prolonged serum half-life of several weeks (Bunn et 
al., 1996; Guttmann et al., 1997). The effects of lymphocyte depletion are persists for years following administration, as evidenced by selectively low $\mathrm{CD} 4^{+} \mathrm{T}$ cell counts (Brennan et al., 1999; Hardinger et al., 2004).

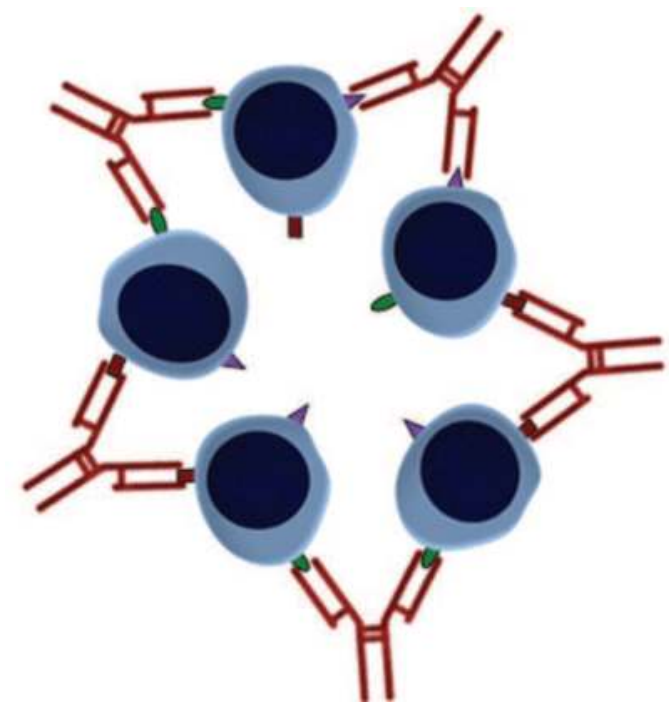

Fig. 3. Polyclonal antibodies. Polyclonal antibodies are non-specific and bind multiple antigens as shown in the figure

\subsubsection{Applications}

Rabbit ATG has been approved for use as an induction agent and for the treatment of acute rejection in Europe since 1984 (IMTIX-SangStat, 2003). However, in the United States, rATG is indicated only for the treatment of acute rejection (as of 1998). Nevertheless, it is routinely administered as induction therapy in many centers in the United States. Early studies demonstrated an increased risk of infectious complications and post-transplant malignancy when administered in conjunction with cyclosporine (Merion et al., 1984). With a better understanding of PTLD, improved infectious prophylaxis protocols, and experience using lower doses of rATG, the use of rATG as an induction agent has increased.

The most effective use of rATG depends on timing of administration. Ideally, the first dose should be given before the vascular anastomosis at the time of transplantation (typical dose $1.5 \mathrm{mg} / \mathrm{kg} /$ dose for a total of 4.5 to $7.5 \mathrm{mg} / \mathrm{kg}$ ). This may minimize ischemia-reperfusion injury and potentially prevent the development of delayed graft function (Shoskes \& Halloran, 1996). Delayed graft function is known to portend poorer outcomes in kidney transplant recipients, thus rATG has been used in patients at higher risk of developing this delayed graft function, including recipients of donation after cardiac death donors, and recipients of extended criteria donors (Beiras-Fernandez et al., 2006; Cecka et al., 1993; Shield et al., 1997). It is also administered in patients at higher risk of developing acute rejection in the perioperative period, such as retransplants and patients who may have prolonged avoidance of calcineurin inhibitors as well as to minimize maintenance therapies such as facilitating early corticosteroid withdrawl (Schaffer et al., 2003; Shield et al., 1997). 
The use of rATG to treat severe or refractory acute cellular rejection episodes has been wellestablished. Refractory acute cellular rejection is defined as failure to respond to 3 consecutive days of bolus methylprednisolone (i.e. $500 \mathrm{mg}$ per day) treatment. rATG is superior to glucocorticoids in treating acute cellular rejection episodes. Compared to other polyclonal antibody formulations, rATG has proven to be superior in reversing steroidresistant rejection and prolonging rejection-free events (Gaber et al., 1998). Patient or graft survival, however, have not been shown to be affected. Given the potency of rATG, it is typically used as supplemental agent to corticosteroids for the treatment of severe or refractory episodes of acute rejection. Additionally, recurrent episodes of acute rejection may be treated with multiple courses of rATG as long as preformed antirabbit antibodies are not present (Bock et al., 1995).

\subsubsection{Adverse effects}

Patients treated with rATG may experience a variety of side effects. It has been associated with a phenomenon called cytokine release syndrome (Fig. 4), which is common to many polyclonal antibody formulations. Patients may experience mild flu-like symptoms, such as fever, chills, nausea, urticaria, rash, and headache (Guttmann et al., 1997). This occurs as a result of increased production of tumor necrosis factor-a, IL-1, and IL-6 from antibody binding to cell surface receptors and ensuing cell lysis (Debets et al., 1989; Guttmann et al., 1997; Hardinger, 2006). Premedication with corticosteroids, antipyretics, and antihistamines can prevent and/or treat the flu-like symptoms that can occur in a subset of kidney transplant recipients. In some cases, patients may develop more severe shock-like reactions, such as dyspnea, severe hypotension, pulmonary edema, or even anaphylaxis. Although patients frequently experience the mild flu-like symptoms and not the more severe reactions, recipient co-morbid conditions, such as cardiac or pulmonary disease, should be considered when selecting rATG as an induction agent. Serum sickness has also been associated with rATG administration in up to 7-10\% of patients (Buchler et al., 2003; Mourad et al., 2001).

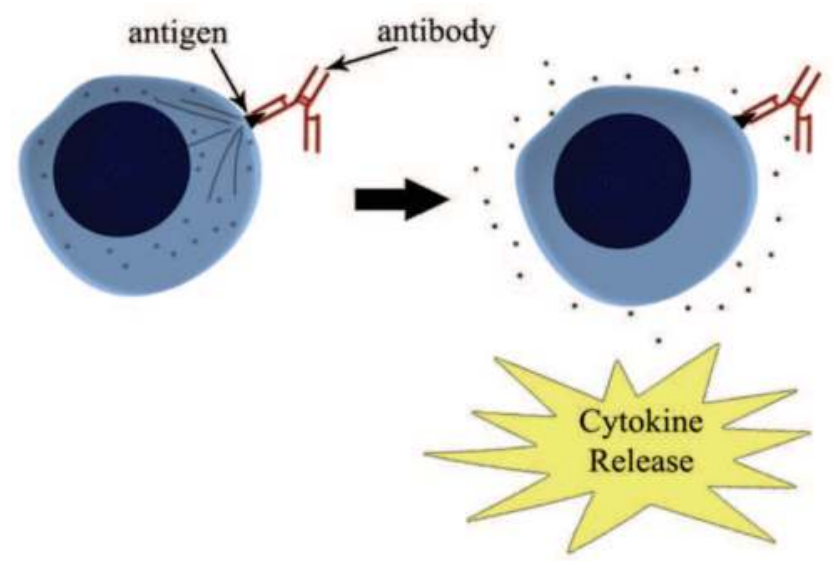

Fig. 4. Antibody activation and cytokine release. Antibodies can bind antigens resulting in activation of the cell and cytokine release as illustrated in the figure 
Hematological adverse events may occur, including leucopenia and thrombocytopenia. It is important to monitor white blood cell, lymphocyte, and platelet counts for patients receiving rATG. Not surprisingly, these events may lead to an increase in infectious complications, including cytomegalovirus (CMV), herpes simplex virus, Epstein-Barr virus (EBV), and varicella (Abott et al., 2002; Gourishankar et al., 2004).

\subsection{Muromonab (OKT3)}

\subsubsection{Mechanism}

Muromonab, or OKT3, is a monoclonal antibody. It is an IgG2 mouse antibody known to bind the epsilon component of human CD3. The CD3 complex is a $\mathrm{T}$ cell receptor intimately involved in $\mathrm{T}$ cell signaling and activation via a calcineurin-dependent pathway (Ortho Multicenter Transplant Study Group, 1985). Once the antibody binds the target cell, complement is activated leading to cell lysis and ADCC (Vallhonrat et al., 1999). By this method, most $T$ cells are effectively removed from the peripheral circulation. However, the $\mathrm{T}$ cell binding also results in $\mathrm{T}$ cell activation before clearance, leading to systemic cytokine release. When OKT3 binds the $\mathrm{T}$ cell receptor, the CD3 complex is internalized (Fig. 5) to prevent further activation by persistent antigen presence (Chatenoud et al., 1990). Effectively, T cells that fail to be cleared are unable to be activated by the CD3 complex.
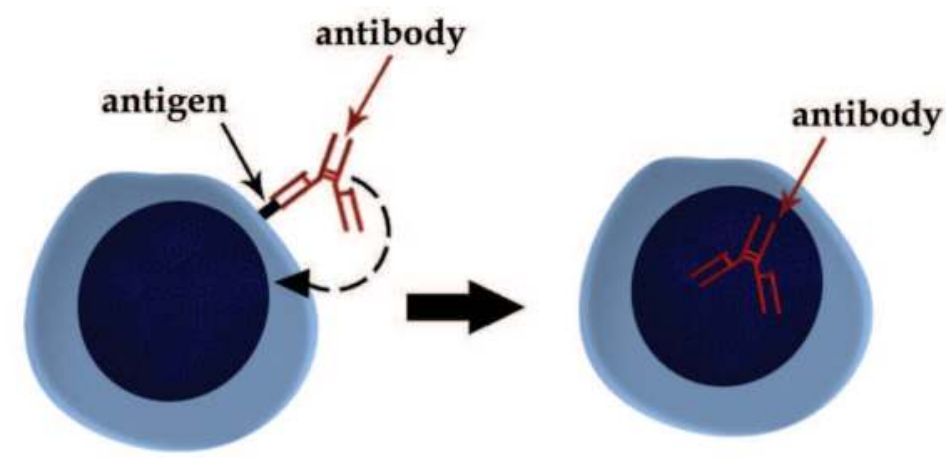

Fig. 5. Internalization of an antibody. This figure is an example of internalization of the antigen-antibody complex after activation to prevent further stimulation by persistently low level of antibody in the peripheral circulation (i.e. OKT3 binding)

\subsubsection{Applications}

Early studies demonstrated the efficacy of OKT3 as an induction agent in kidney transplantation in conjunction with maintenance immunosuppression (Debure et al., 1988; Norman et al., 1988; Vigeral et al., 1986). Efficacy relies on serum availability, thus once administration of OKT3 ceases, maintenance immunosuppressive therapy is required. Typical dosing is 5 to $10 \mathrm{mg} /$ dose through a peripheral or central line. Premedication with methylprednisolone, acetaminophen, and diphenhydramine can significantly lower the amount of cytokine release associated with first infusion (Chatenoud et al., 1991). Additionally, slower administration rates are helpful in blunting the cytokine response. Dosing can be continued for up to 14 days for a total dose of $70 \mathrm{mg}$. Patients with 
significant sensitization have especially benefitted from OKT3 (Opelz, 1995). In addition, recipients of renal allografts experiencing delayed graft function benefit from OKT3 infusion, as calcineurin inhibitor therapy can be delayed, avoiding added renal toxicity (Benvenisty et al., 1990).

Early studies of OKT3 demonstrated a reduction in acute rejection rates and time to first rejection episodes; however, overall patient and graft survival rates were not changed (Henry et al., 2001; Norman et al., 1993). Its use has been linked to various infectious and malignant morbidities. Aseptic meningitis has also been linked to its use (Martin et al., 2002). Moreover, PTLD rates are significantly increased, especially in EBV negative recipients receiving EBV positive allografts (Thistlethwaite et al., 1988; Cherikh et al., 2003). The significant side effect profile and immunogenicity of OKT3 has lead to a decline in its use as an induction agent.

OKT3 remains an effective treatment for severe episodes of acute cellular rejection, or those refractory to steroid therapy and rATG. In the majority of cases of vigorous rejection, OKT3 has proven efficacious (Cosimi et al., 1981b; Ortho Multicenter Transplant Study Group, 1985; Thistlethwaite et al., 1987). The efficacy of OKT3 is maintained even if prior lymphocyte depleting agents have been used (Ponticelli et al., 1987). However, timing of therapy is important, as a delay in treatment following the 3 days of high-dose methylprednisolone therapy for steroid-resistant acute rejection is associated with decreased success (Tesi et al., 1993). OKT3 has also been used to treat vascular rejection episodes (Banff grade 2 or 3) (Kamath et al., 1997).

\subsubsection{Adverse effects}

As a monoclonal antibody, OKT3 selectively targets $\mathrm{T}$ cells, avoiding the leucopenia and thrombocytopenia associated with rATG. Similar to rATG, OKT3 is associated with cytokine release syndrome. With respect to OKT3, this is more pronounced, especially with the first dose as the $\mathrm{T}$ cells may be in a more activated state (i.e. acute cellular rejection). The cytokine release syndrome with OKT3 results in severe flu-like symptoms, including fever, chills, malaise, nausea, vomiting, and even rigors (Thistlethwaite et al., 1988). As vascular permeability increases, patients may experience pulmonary edema, hypotension, and volume overload. If there is renal dysfunction present, patients should undergo hemodialysis prior to first infusion to avoid volume-related complications. Patients should be closely monitored, especially during the initial infusions for cardiac or pulmonary complications.

The utilization of OKT3 is clearly associated with antimouse antibodies in at least $30 \%$ of patients, depending on the immunosuppression regimens used at the time (Colvin \& Preffer, 1991; Schroeder et al., 1990). The antibodies form against the mouse IgG molecule. If there is antibody formation, OKT3 is typically not reused, although higher doses may overcome this. This can be documented by laboratory evidence of antimouse antibody (Chatenoud et al., 1986; Legendre et al., 1992).

\subsection{Alemtuzumab}

\subsubsection{Mechanism}

Alemtuzumab, or Campath-1H, is a monoclonal antibody to rat antihuman CD52 (Fig. 6). It is an IgG1 humanized molecule (Hale et al., 1986). CD52 is present in high abundance on most lymphocytes, including $\mathrm{T}$ cell, $\mathrm{B}$ cells, and monocytes, but not hematopoietic 
precursors (Hale, 2001). It effectively depletes T cells, and some B cells and monocytes in the circulation as well as the allograft (Kirk et al., 2003).

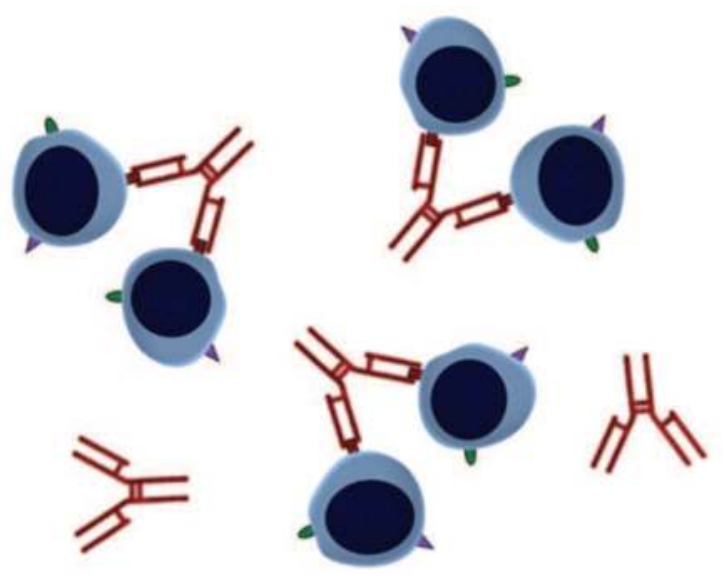

Fig. 6. Monoclonal antibodies. Monoclonal antibodies are specific and bind a single antigen as shown in the figure

\subsubsection{Applications}

Alemtuzumab has not been approved for use as an induction agent; however, this is a common off-label use. Currently, it is only approved to treat lymphogenous malignancies. As an off-label induction agent, it's been used with various immunosuppression regimens, including steroid-sparing regimens. Effectively, it depletes lymphocytes at the time of transplantation and last for several months to a year before the immune system is reconstituted (Gabardi et al., 2011). Alemtuzumab is given at a dose of $30 \mathrm{mg}$ or $0.3 \mathrm{mg} / \mathrm{kg}$ through a peripheral line over 3 hours. Sometimes 2 doses are given, although $\mathrm{T}$ cells are expectedly removed within 1 hour of initial administration (Kirk et al., 2003; Pearl et al., 2005).

Alemtuzumab depletes all T cell subsets, but has a predilection for more naïve T cells (Pearl et al., 2005). Memory T cell subsets may not be depleted with this therapy, but these cell types are especially susceptible to calcineurin inhibitors. Because of the prompt and intense depletion, alemtuzumab is especially appealing to use in patients with delayed graft function, as calcineurin inhibitor therapy can be withheld to avoid concomitant calcineurininduced renal insults.

Early studies of alemtuzumab demonstrated its efficacy as a treatment therapy for acute rejection; however, it was associated with significant infectious morbidity and mortality (Hale et al., 1986). Patients were significantly over-immunosuppressed, especially on a triple maintenance therapy. More recent literature has been small studies or anecdotal data (Clatworthy et al., 2009; Csapo et al., 2005; Jirasiritham et al., 2010). Because its efficacy is greatest against naïve $\mathrm{T}$ cells, its use in sensitized patients may-be limited.

In a recent study, alemtuzumab was prospectively compared to basiliximab and rATG as an induction agent in patients on a steroid-sparing immunosuppressive regimen (Hanaway et al., 2011). Alemtuzumab demonstrated lower short-term rates of acute rejection compared to 
basiliximab in patients at low-risk of developing acute rejection. At 3-years, however, the rates of acute rejection were no different between alemtuzumab and rATG. Additionally, patients receiving alemtuzumab did not experience an increased incidence of adverse events.

\subsubsection{Adverse effects}

Similar to other depleting agents (rATG and OKT3), alemtuzumab is also associated with cytokine release syndrome, albeit to a lesser extent. If properly premedicated with methylprednisolone, acetaminophen, and diphenhydramine, the cytokine release is blunted. Urticaria and rash manifestations are common, while anaphylaxis and hypotension have also been reported. It has not been associated with antibody formation, as in the case of OKT3. It has been linked to the development of autoimmune thyroiditis in patients treated with alemtuzumab for multiple sclerosis (Coles et al., 1999). This has also been reported in a renal transplant recipient treated with alemetuzumab (Kirk et al., 2006).

\section{Non-depleting agents}

\subsection{Basiliximab}

\subsubsection{Mechanism}

Basiliximab is a chimeric mouse-human monoclonal IgG1 antibody to CD25. CD25 is the asubunit of the IL-2 receptor, which is a binding site of IL-2. Basiliximab inhibition of IL-2 binding occurs through steric hindrance (Fig.7). In this case, the effect is not depletional, but rather, preventative of early T cell activation (Gabardi et al., 2011).

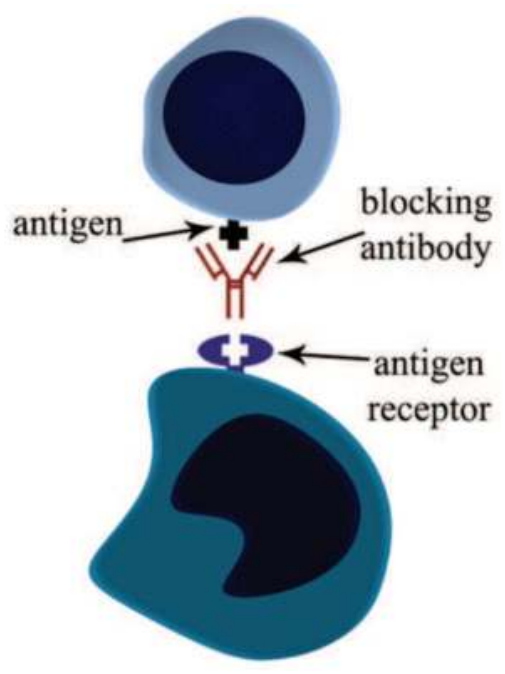

Fig. 7. Antibody blockade. In this figure the antibody functions by blocking the antigen from binding to the receptor

\subsubsection{Applications}

Basiliximab's biological bias for naïve $\mathrm{T}$ cells has limited its role to an induction agent. One dose is typically administered on the day of transplant as well as one dose on postoperative 
day 4 (20 mg per dose) through a peripheral line. Its use has been associated with decreased rates of acute cellular rejection compared to no formal induction agent (besides methylprednisolone) on triple or double drug immunosuppression regimens (Kahan et al., 1999; Nashan et al., 1997). Additional studies comparing basiliximab induction to polyclonal antibody depleting induction agents in the setting of triple maintenance immunosuppression regimens have shown similar outcomes, including acute rejection rates and delayed graft function (Lebranchu et al., 2002; Mourad et al., 2004). Basiliximab induction has also been used in steroid avoidance immunosuppression regimens (Afaneh et al., 2010). In the setting of monotherapy or calcineurin inhibitor free regimens, basiliximab has not been shown to be useful (Parrott et al., 2005; Vincenti et al., 2001). In some instances of excellent allograft human leukocyte antigen (HLA)-matching (i.e. 2haplotype matches), it's been used as an effective induction agent with steroid-sparing immunosuppressive regimens (Afaneh et al., 2010). Given the relatively mild side effect profile, basiliximab is well-tolerated in all patients, even those with significant cardiac or pulmonary co-morbidities. It has no role in the treatment of acute rejection episodes as a rescue agent.

\subsubsection{Adverse effects}

Because of the mechanism of action of basiliximab, the side effect profile is relatively mild (Kahan et al., 1999; Nashan et al., 1997). Cytokine release syndrome does not occur, as T cells are not activated or stimulated. The most serious adverse event is hypersensitivity, which is rare $(<1 \%)$ (Gabardi et al., 2011). There is no increased risk of infectious complications or PTLD compared to no induction therapy (Cherikh et al., 2003).

\subsection{Daclizumab}

\subsubsection{Mechanism}

Similar to basiliximab, daclizumab is an antagonist to CD25; however, it is a humanized IgG1 antibody. The CD25 molecule was the first humanized monoclonal antibody to be successfully targeted in the field of transplantation (Kirkman et al., 1991). The mechanism of action of daclizumab essentially duplicates that of other IL-2 receptor antagonists.

\subsubsection{Applications}

Like basiliximab, daclizumab has been shown to decrease the incidence of acute cellular rejection when administered as an induction agent (Hershberger et al., 2005; Nashan et al., 1999). Given the favorable side effect profile, it is tolerated well in recipients, irrespective of co-morbid conditions. The main disadvantage of daclizumab, as compared to basiliximab, is that it is more costly and requires repeated administrations (Gabardi et al., 2011). Because the demand for the medication has been relatively low, it has been discontinued by the manufacturer. It has no role as a rescue agent for acute rejection.

\subsubsection{Adverse effects}

The side effect profile is similar to that of basiliximab and generally favorable. Cytokine release is not typically associated with this agent (Hershberger et al., 2005; Nashan et al., 1999). Like other IL-2 receptor antagonists, the risk of PTLD is not significantly increased with use (Cherikh et al., 2003). 


\section{Desensitizing agents}

\subsection{Rituximab}

\subsubsection{Mechanism}

Rituximab is a monoclonal chimeric antibody to the CD20 molecule. CD20 is a glycoprotein on the cell surface of circulating, mature B cells. Rituximab effectively depletes CD20 ${ }^{+}$cells from the circulation by inducing apoptosis (Deans et al., 2002). These cells are precursors to antibody-producing plasma cells, and their role in transplantation is only partially characterized. They may play a role in acute rejection, as B cells can act as antigenpresenting cells.

\subsubsection{Applications}

Rituximab is approved for use in various lymphomas, leukemias, PTLD, and rheumatoid arthritis (Gabardi et al., 2011; Grillo-Lopez et al., 1999). Peripheral veins can be used for administration and dosing is dependent on the indication. A recent study examining the role of rituximab as an induction agent found no benefit compared to placebo (Tyden et al., 2009). However, it does play a role as a desensitizing agent in patients with preformed donor specific antibodies (DSA), in conjunction with total plasmapheresis and/or intravenous immunoglobulin (IVIG)(Fuchinoue et al., 2011; Sonnenday et al., 2004). Additionally, it has been used to aid in transplanting across blood group barriers in donor recipient pairs and in patients with positive crossmatches following antibody elimination. Rituximab is increasingly being used to treat episodes of vascular rejection and antibodymediated rejections (Y.T. Becker et al., 2006; Fehr et al., 2009). Finally, rituximab is a proven and effective agent in the treatment of PTLD (Svoboda et al., 2006). Administration does not replace immunosuppression reduction or chemotherapy, but rather supplements the other modalities.

\subsubsection{Adverse effects}

Rituximab is generally well-tolerated with minimal side effects. Anaphylaxis remains a theoretical concern, as is the case with most agents. Reports on infectious complications related to rituximab have been variable (Grim et al., 2007; Kamar et al., 2010; Nishida et al., 2009). In some instances there was no difference in bacterial, viral, or fungal infections in kidney transplant recipients treated with rituximab, however, this remains controversial.

\subsection{Bortezomib}

\subsubsection{Mechanism}

Bortezomib is a proteasomal inhibitor that causes apoptosis of plasma cells. It binds the $26 \mathrm{~S}$ subunit of the proteasome (Bonvini et al., 2007). Proteasome inhibition ultimately leads to apoptosis during mitosis. Bortezomib selectively causes apoptosis in CD138 ${ }^{+}$plasma cells (Perry et al., 2009). Additionally, Bortezomib may block T cell cycling and decrease the number of circulating B cells by reducing bone marrow levels of IL-6 (San Miguel et al., 2008).

\subsubsection{Applications}

Bortezomib has not been approved for use in kidney transplantation; however, it has been used in sensitized patients (Perry et al., 2009). Bortezomib has been successfully used to decrease DSA levels, which may play a role in acute antibody-mediated rejection (AMR) 
(Trivedi et al., 2009). Furthermore, in vivo data has demonstrated a decrease in the percentage of bone marrow plasma cells, antibody production, and allospecificities of plasma cells in bone marrow aspirates of patients treated with bortezomib $\mathrm{i}$ in the setting of AMR (Perry et al., 2009).

\subsubsection{Adverse events}

Bortezomib has been associated with various side effects. Although gastrointestinal side effects are the most common, peripheral neuropathy has also been reported, especially in patients with a pre-existing history of neuropathy (Bonvini et al., 2007). Moreover, myelosuppression and shingles has been reported.

\subsection{Intravenous Immunoglobulin (IVIG)}

\subsubsection{Mechanism}

Intravenous immunoglobulin, or IVIG, is pooled polyclonal antibodies from different human donors. These are high-dose human IgG fractions with a wide range of specificities. These are non-T cell specific formulations and have no specific cell targets (Jordan et al., 2011). It is able to bind activated complement components or even inhibit complement activation (Jordan et al., 2009). IVIG may also modulate the alloimmune response by binding to the Fc receptor of antigen-presenting cells, effectively quelling the alloimmune response (Kazatchkine \& Kaveri, 2001).

\subsubsection{Applications}

Despite the inability to deplete T cells, IVIG is an effective treatment of acute cellular rejection. Early studies showed that IVIG was as effective as OKT3 in reversing steroidresistant acute rejection episodes (Casadei et al., 2001). In the setting of antibody-mediated rejection, IVIG has been shown to be beneficial when used in conjunction with plasmapheresis and/or rituximab (Lefaucher et al., 2009; Shehata et al., 2010). As a desensitization agent alone, no study has demonstrated a clear benefit (Pisani et al., 1999; Shehata et al., 2010). Definitive reduction of antibody was not shown and a survival advantage was not evident.

\subsubsection{Adverse effects}

The side-effect profile of IVIG increases with dosing. High-dose IVIG is associated with more infusion-related complications, such as headache, thrombotic incidents, hemolysis, bronchospasms, osmotic nephropathy, or even aseptic meningitis (Jordan et al., 2011; Kahwaji et al., 2009). Sucrose-based and high osmolality products have a higher risk of developing osmotic nephropathy as opposed to other preparation. Nevertheless, it is typically well-tolerated, especially at lower doses and most patients report only headache.

\section{Experimental agents}

\subsection{Siplizumab (MEDI-507)}

Originally described as BTI-322, siplizumab is a monoclonal humanized antibody to CD2. It is an IgG1k molecule derived from rat (Pruett et al., 2009). CD2, or lymphocyte functionassociated antigen-2 (LFA-2), is an important T cell adhesion molecule that binds to CD58, or LFA-3. This is a transmembrane signal transduction molecule that facilitates $\mathrm{T}$ cell 
receptor binding. Early studies examined the use of siplizumab as an induction agent and treatment modality for acute rejection in solid organ transplantation as well as graft-versushost disease (Pruett et al., 2009; Squifflet et al., 1997). The first human study of siplizumab demonstrated the safety and feasibility in kidney transplantation, as compared to placebo; however, current endeavors are focused on investigating its use in nonmyeloablative conditioning regimens to achieve mixed chimerism (Kawai et al., 2008; Pruett et al., 2009; Spitzer et al., 2003). In addition, it is being investigated for the treatment of plaque psoriasis (Langley et al., 2010).

\subsection{Alefacept}

Alefaept is a dimeric fusion protein (Fig.8) constituted from LFA-3 and the human Fc portion of IgG1. Studies have demonstrated inhibition of $\mathrm{T}$ cell proliferation and depletion of effector memory T cells (Ellis \& Krueger, 2001; Gordon et al., 2003). Currently, alefacept is approved to treat plaque psoriasis. Preclinical studies in nonhuman primates have demonstrated a survival benefit of alefacept, when used in conjunction with costimulatory blockade, but not alone; however in human trials have never shown a benefit (Weaver et al., 2009).

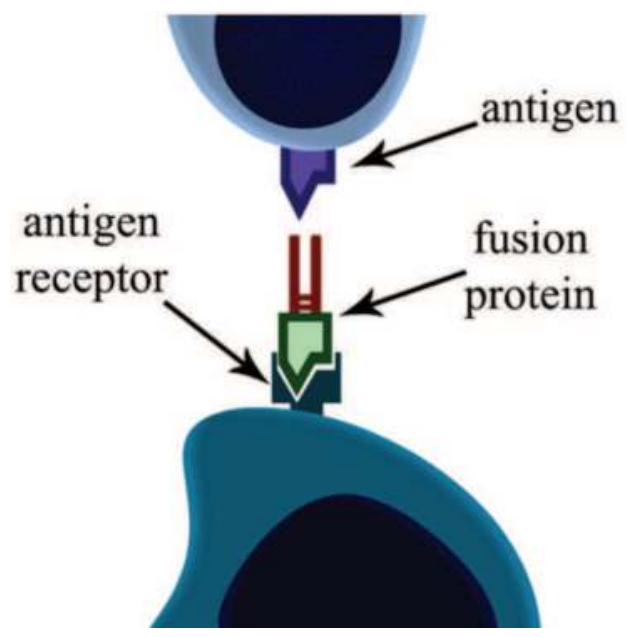

Fig. 8. Mimicry. In this figure, the antibody is fused with a protein structural similar to the intended antigen, which can serve as activating or inhibitory

\subsection{Costimulatory blockade}

\subsubsection{Abatacept}

Abatacept is a recombinant cytotoxic T-lymphocyte antigen 4 (CTLA4) fused with the Fc portion of IgG1 (Lenschow et al., 1992; Turka et al., 1992). Animal models demonstrated its ability to delay or even prevent the onset of allograft rejection, which is comparable to basiliximab and some polyclonal antibody therapies (Kirk et al., 1997; Lenschow et al., 1992; Turka et al., 1992). It has been approved for treatment of rheumatoid arthiritis (Genovese et al., 2005; Nogid \& Pham, 2006). Further investigations of this medication are not currently under development. 


\subsubsection{Belatacept}

Belatacept is the improved version of abatacept, providing selective blockade of $\mathrm{T}$ cell activation as a fusion protein. Two amino acids have been changed to improve dissociation rates when binding to CD80 and CD86 (Vincenti et al., 2005, 2010). In the phase II trial comparing belatacept to cyclosporine, acute rejection rates were similar, while allograft function was significantly improved in patients receiving belatacept (Vincenti et al., 2005). In the phase III trial of kidney transplantation, patients receiving belatacept experienced improved allograft function at 12 months; however, acute rejection rates and severity of acute rejection episodes were significantly higher in the belatacept arm of the study. Additionally, the incidence of PTLD was greater in patients receiving belatacept (Vincenti et al., 2010). An additional study investigating the efficacy of belatacept in kidney transplantation of extended criteria donors demonstrated similar results, with a predilection towards central nervous system (CNS) forms of PTLD (Durrbach et al., 2010). The novelty of costimulation blockade is the ability to avoid calcineurin inhibitors, especially in allografts at increased risk of delayed graft function. Belatacept has recently been approved for the prophylaxis of organ rejection in adult patients receiving a kidney transplant, in combination with basiliximab induction, mycophenolate mofetil, and corticosteroids (Bristol-Myers Squibb Company 2011). Current recommendations include using it only in patients who are EBV seropositive; however, patients should be monitored for an increased risk of infectious complications and Progressive Multifocal Leukoencephalopathy.

\subsubsection{CD7 antagonism}

SDZCHH380 is a monoclonal antibody targeting CD7. This IgG1 chimeric mouse antibody was initially studied in kidney transplantation (Lazarovits et al., 1993; Sharma et al., 1997). The CD7 molecule is expressed on $\mathrm{T}$ cells and natural killer cells during early differentiation, functioning as a costimulatory molecule. Early studies of SDZCHH380 as an induction agent in kidney transplantation demonstrated comparable short and long-term outcomes to OKT3 induction (Sharma et al., 1997). Despite favorable results up to 4 years following administration, further investigative endeavors were not pursued in solid organ transplantation.

\subsection{4 $\mathrm{T}$ cell receptor antagonism}

T10B9, or Medi-500, is a monoclonal antibody to the T cell receptor. Specifically, this is a murine IgMк molecule to the $\alpha \beta$ heterodimer region of the CD3 complex (Brown et al., 1996; Waid et al., 1992, 2009). Because it does not bind directly to the Fc receptor, there is reduced immune stimulation and occurrence of cytokine release syndrome. The end result is $\mathrm{T}$ cell depletion. Early studies demonstrated the efficacy of this agent as induction therapy and a treatment modality for acute rejection in solid organ transplantation, as compared to OKT3 (Waid et al., 1997a, 1997b). However, given the efficacy of similar humanized monoclonal antibodies, further investigations in solid organ transplantation were not pursued.

\section{Special considerations}

\subsection{High risk donor kidneys \& recipients}

Marginal donor kidneys are defined as expanded criteria donors (ECD) or donation after cardiac death donors (DCD). These allografts are at higher risk of developing delayed graft 
function, which has been shown to decrease overall allograft survival and increase the incidence of acute rejection (Deroure et al., 2010; Rudich et al., 2002). There was a large prospective, international, randomized controlled trial examining the efficacy of rATG versus basiliximab in patients at high risk of delayed graft function (Brennan et al., 2006). Patients were maintained on a cyclosporine-based triple drug immunosuppression regimen and eligibility criteria included ECD or DCD allografts, standard criteria donors (SCD) with greater than 24 hours of cold ischemia time, repeat transplants, panel-reactive antibody value exceeding $20 \%$ before transplantation, donors with acute tubular necrosis (ATN), recipient black race, or one or more HLA mismatches. The incidence of delayed graft function was not significantly different between patients receiving rATG and basiliximab induction. However, the incidence of biopsy-proven acute rejection was significantly lower in patients receiving rATG. Additionally, severe rejection episodes requiring antibody therapy were less frequent in the rATG group. Interestingly, the overall incidence of infection was significantly lower in the basiliximab group, yet the incidence of CMV was lower in the rATG group.

\subsection{Sensitization \& incompatibility}

Sensitization to HLA antigen typically occurs as a result of blood transfusions, pregnancy, or previous transplantation (Marfo et al., 2011). These patients are more likely develop circulating DSA and have a positive cross-match during transplantation evaluation. Sensitized patients wait considerable longer on the deceased donor waitlist.

Various modalities have been developed to combat sensitization. Antibodies can be removed by plasmapheresis and immunoadsorption techniques; however anti-HLA antibodies generally rebound and return to baseline (Hakim et al., 1990). As discussed earlier, rituximab has also been used with varying success, as B cells recovery occurs 6 to 12 months following administration. Bortezomib has been used in sensitized patients (Perry et al., 2009). Recently, a new medication called eculizumab has emerged as a humanized monoclonal antibody to complement component 5 (C5) to mediate complement-mediated injury, which may have potential in desensitization protocols (Larrea et al., 2010). IVIG has also been used in sensitized patients to acutely decrease PRA levels, especially in ABOincompatible patients. Finally, splenectomy has also been used in desensitization protocols of ABO-incompatible patients (Kaplan et al., 2007).

Despite these numerous combinations of these therapies with acceptable short-term outcomes, intermediate-term outcomes have been modest at best. Some have reported graft survival rates at 3 years to be $78 \%$ (Haririan et al., 2009) and 4-year graft survival of only $66 \%$ (Lefaucher et al., 2007). Additionally, higher rates of clinical and subclinical antibodymediated rejection have been reported (Haas et al, 2007; Loupy et al., 2009).

\subsection{Older recipients}

Several considerations should be examined when choosing induction therapy in older recipients. Older patients may have lower rates of acute rejection as a result of diminished immune activity (B.N. Becker 1996; Friedman et al., 2004). There is also a higher rate of infectious complications as well as malignancies (Meier-Kriesche et al., 2001; Stratta et al., 2008). Thus, less intense induction and immunosuppression appear sufficient. However, if significant HLA-mismatch is present, higher rates of acute rejection have been described (Frei et al., 2008; Fritsche et al., 2003; Giessing et al., 2003). Nevertheless, the safety profile of 
IL-2 receptor antibodies in patients with considerable comorbidities, such as the older recipients, may be preferred.

\section{Acknowledgements}

The authors gratefully acknowledge the expert assistance of Ms. Johanna Martin in creating all figures depicted in the chapter.

\section{References}

Abott, K.C.; Hypolite, I.O.; Viola, R., et al. (2002). Hospitalizations for cytomegalovirus disease after renal transplantation in the United States. Ann Epidemiol, Vol.12, No.6, (August 2002), pp. 402-409, ISSN 1047-2797.

Afaneh, C.; Halpern, J.; Cheng, E., et al. (2010). Steroid avoidance in two-haplotype-matched living donor renal transplants with basiliximab induction therapy. Transplant Proc, Vol.42, No.10, (December 2010), pp. 4526-9, ISSN 0041-1345.

Becker, B.N.; Ismail, N.; Becker, Y.T., et al. (1996). Renal transplantation in the older end stage renal disease patient. Semin Nephrol, Vol.16, No.4, (July 2006), pp. 353-62, ISSN 0720-9295.

Becker, Y.T.; Samaniego-Picota, M., \& Sollinger, H.W. (2006). The emerging role of rituximab in organ transplantation. Transpl Int, Vol.19, No.8, (August 2006), pp. 621-8, ISSN 0934-0874.

Beiras-Fernandez, A.; Chappell, D.; Hammer, C., et al. (2006). Influence of polyclonal antithymocyte globulins upon ischemia reperfusion injury in a non-human primate model. Transpl Immunol, Vol.15, No.4, (April 2006), pp. 273-9, ISSN 0966-3274.

Benvenisty, A.I.; Cohen, D.; Stegall, M.D., et al. (1990). Improved results using OKT3 as induction immunosuppression in renal allograft recipients with delayed graft function. Transplantation, Vol.49, No.2, (February 1990), pp. 321-7, ISSN 00411337.

Bishop, G.; Cosimi, A.B.; Voynow, N.K., et al. (1975). Effect of immunosuppressive therapy for renal allografts on the number of circulating sheep red blood cells rosetting cells. Transplantation, Vol.20, No.2, (Augusut 1975), pp. 123-9, ISSN 0041-1337.

Bock, H.A.; Gallati, H.; Zurcher, R.M., et al. (1995). A randomized prospecitve trial of prophylactic immunosuppression with ATG-Fresenius versus OKT3 after renal transplantation. Transplantation, Vol.59, No.6, (March 1995), pp. 830-40, ISSN 00411337.

Bonnefoy-Berard, N.; Vincent, C., \& Revillard, J. (1991). Antibodies against the functional leukocyte surface molecules in polyclonal antilymphocyte and antithymocyte globulins. Transplantation, Vol.51, No.3, (March 1991), pp. 669-73, ISSN 0041-1337.

Bonvini, P.; Zorzi, E.; Basso, G., et al. (2007). Bortezomib-mediated $26 \mathrm{~S}$ proteasome inhibition causes cell-cycle arrest and induces apoptosis in CD-30+ anaplastic large cell lymphoma. Leukemia, Vol.21, No.4 (April 2007), pp. 838-42, ISSN 0887-6924.

Boulianne, G.L.; Hozumi, N.; Shulman, M.J., et al. (1984). Production of functional chimaeric mouse/human antibody. Nature, Vol.312, No.5995, (December 1984), pp. 643-6, ISSN 0028-0836.

Brennan, D.C.; Flavin, K.; Lowell, J.A., et al. (1999). A randomized,double-blinded comparison of thymoglobulin versus Atgam for induction immunosuppressive 
therapy in adult renal transplant recipients. Transplantation, Vol.67, No.7, (April 1999), pp. 1011-8, ISSN 0041-1337.

Brennan, D.C.; Daller, J.A.; Lake, K.D., et al. (2006). Rabbit antithymocyte globulin versus basiliximab in renal transplantation. $N$ Engl J Med, Vol.355, No.19, (November 2006), pp. 1967-77, ISSN 0028-4793.

Bristol-Myers Squibb Company. (2011). Nulojix® (belatacept) prescribing information. Princeton, New Jersey, USA; (2011).

Brown, S.A.; Lucas, B.A.; Waid, T.H., et al. (1996). T10B9 (MEDI-500) mediated immunosuppression: studies on the mechanism of action. Clin Transplant, Vol.10, No.6, (December 1996), pp. 607-13, ISSN 0902-0063.

Buchler, M.; Hurault de Ligny, B.; Madec, C., et al. (2003). Induction therapy by antithymocyte globulin (rabbit) in renal transplantation: a 1-yr follow-up of safety and efficacy. Clin Transplant, Vol.17, No.6, (December 2003), pp. 539-45, ISSN 0902-0063.

Bunn, D.; Lea, C.K.; Bevan, D.J., et al. (1996). The pharmacokinetics of anti-thymocyte globulin (ATG) following intravenous infusion in man. Clin Nephrol, Vol.45, No.1, (January 1996), pp. 29-32, ISSN 0301-0430.

Bustami, R.T.; Ojo, A.O.; Wolfe, R.A., et al. (2004). Immunosuppression and the risk of posttransplant malignancy among cadaveric first kidney transplant recipients. Am J Transplant, Vol.4, No.1, (January 2004), pp. 87-93, ISSN 1600-6135.

Capra, J.D., \& Edmundson, A.B. (1977). The antibody combining site. Sci Am, Vol.236, No.1, (January 1977), pp. 50-9, ISSN 0036-8733.

Casadei, D.H.; del C Rial, M.; Opelz, G., et al. (2001). A randomized and prospective study comparing treatment with high-dose intravenous immunoglobulin with monoclonal antibodies for rescue of kidney grafts with steroid-resistant rejection. Transplantation, Vol.71, No.1, (January 2001), pp. 53-8, ISSN 0041-1337.

Cecka, J.M.; Gjertson, D., \& Terasaki, P. (1993). Do prophylactic antilymphocyte globulins (ALG and OKT3) improve renal transplant in recipient and donor high-risk groups? Transplant Proc, Vol.25, No.1, (February 1993), pp. 548-9, ISSN 0041-1345.

Chatenoud, L.; Jonker, M.; Villemain, F., et al. (1986). The human immune response to the OKT3 monoclonal antibody is oligoclonal. Science, Vol.232, No.4756), (June 1986), pp. 1406-8, ISSN 0036-8075.

Chatenoud, L.; Ferran, C.; Legendre, C., et al. (1990). In vivo cell activation following OKT3 administration: systemic cytokine release and modulation by corticosteroids. Transplantation, Vol.49, No.4, (April 1990), pp. 697-702, ISSN 0041-1337.

Chatenoud, L.; Legendre, C.; Ferran, C., et al. (1991). Corticosteroid inhibition of the OKT3induced cytokine-related syndrome- dosage and kinetics prerequisites. Transplantation, Vol.51, No.2, (February 1991), pp. 334-8, ISSN 0041-1337.

Cherikh, W.S.; Kauffman, H.M.; McBride, M.A., et al. (2003). Association of the type of induction immunosuppression with posttransplant lymphoproliferative disorder, graft survival, and patient survival after primary kidney transplantation. Transplantation, Vol.76, No.9, (Novemeber 2003), pp. 1289-93, ISSN 0041-1337.

Clatworthy, M.R.; Friend, P.J.; Calne, R.Y., et al. (2009). Alemtuzumab (CAMPATH-1H) for the treatment of acute rejection in kidney transplant recipients: long-term followup. Transplantation, Vol.87, No.7, (April 2009), pp. 1092-5, ISSN 0041-1337. 
Coles, A.J.; Wing, M.; Smith, S., et al. (1999). Pulsed monoclonal antibody treatment and autoimmune thyroid disease in multiple sclerosis. Lancet, Vol.354, No.9191, (Novemeber 1999), pp. 1691-5, ISSN 0140-6736.

Colvin, R.B., \& Preffer, F.I. (1991). Laboratory monitoring of therapy with OKT3 and other murine monoclonal antibodies. Clin Lab Med, Vol.11, No.3, (September 1991), pp. 693-714, ISSN 0272-2712.

Cosimi, A.B.; Wortis, H.H.; Delmonico, F.L., et al. (1976). Randomized clinical trial of antilthymocyte globulin in cadaver renal allograft recipients: importance of $\mathrm{T}$ cell monitoring. Surgery, Vol.80, No.2, (August 1976), pp. 155-63, ISSN 0039-6060.

Cosimi, A.B. (1981a). The clinical value of antilymphocyte antibodies. Transplant Proc, Vol.13, No.1, (March 1981), pp. 462-8, ISSN 0041-1345.

Cosimi, A.B.; Burton, R.C.; Colvin, R.B., et al. (1981b). Treatment of acute renal allograft rejection with OKT3 monoclonal antibody. Transplantation, Vol.32, No.6, (December 1981), pp. 535-9, ISSN 0041-1337.

Csapo, Z.; Benavides-Viveros, C.; Podder, H., et al. (2005). Campath-1H as rescue therapy for the treatment of acute rejection in kidney transplant patients. Transplant Proc, Vol.37, No.5, (June 2005), pp. 2032-6, ISSN 0041-1345.

Deans, J.P.; Li, H.; Polyak, M.J., et al. (2002). CD20-mediated apoptosis: signaling through lipid rafts. Immunology, Vol.107, No.2, (October 2002), pp. 176-82, ISSN 0019-2805.

Debets, J.M.H.; Leunissen, K.M.L.; van Hooff, H.J., et al. (1989). Evidene of involvement of tumor necrosis factor in adverse reactions during treatment of kidney allograft rejection with antithymocyte globulin. Transplantation, Vol.47, No.3, (March 1989), pp. 487-92, ISSN 0041-1337.

Debure, A.; Chekoff, N.; Chatenoud, L., et al. (1988). One-month prophylactic use of OKT3 in cadaver kidney transplant recipients. Transplantation, Vol.45, No.3, (March 1988), pp. 546-53, ISSN 0041-1337.

Deroure, B.; Kamar, N.; Depreneuf, H., et al. (2010). Expanding the criteria of renal kidneys for transplantation: use of donors with acute renal failure. Nephrol Dial Transplant, Vol.25, No.6, (June 2010), pp. 1980-6, ISSN 0931-0509.

Durrbach, A.; Pestana, J.M.; Pearson, T., et al. (2010). A phase III study of belatacept versus cyclosporine in kidney transplants from extended criteria donors (BENEFIT-EXT study). Am J Transplant, Vol.10, No.3, (March 2010), pp. 547-57, ISSN 1600-6135.

Ellis, C.N.; Krueger, G.G. \& Alefacept Clinical Study Group. (2001). Treatment of chronic plaque psoriasis by selective targeting of memory effector T lymphocytes. $\mathrm{N} \mathrm{Engl} \mathrm{J}$ Med, Vol.345, No.4, (July 2001), pp. 248-55, ISSN 0028-4793.

Fehr, T.; Rüsi, B.; Fischer, A., et al. (2009). Rituximab and intravenous immunoglobulin treatment of chronic antibody-mediated kidney allograft rejection. Transplantation, Vol.87, No.12, (June 2009), pp. 1837-41, ISSN 0041-1337.

Ferrant, J.L.; Benjamin, C.D.; Cutler, A.H., et al. (2004). The contribution of the Fc effector mechanisms in the efficacy of anti-CD154 immunotherapy depends on the nature of the immune challenge. Int Immunol, Vol.16, No.11, (Novemeber 2004), pp. 158394, ISSN 0953-8178.

Frei, U.; Noeldeke, J.; Machold-Fabrizii, V., et al. (2008). Prospective age-matching in elderly kidney transplant recipients - a 5-year analysis of the Eurotransplant Senior Program. Am J Transplant, Vol.8, No.1, (January 2007), pp. 50-7, ISSN 1600-6135. 
Friedman, A.L.; Goker, O.; Kalish, M.A., et al. (2004). Renal transplant recipients over aged 60 have diminished immune activity and a low risk of rejection. Int Urol Nephrol, Vol.36, No.3, (2004), pp. 451-6, ISSN 0301-1623.

Fritsche, L.; Horstrup, J.; Budde, K., et al. (2003). Old-for-old kidney allocation allows successful expansion of the donor and recipient pool. Am J Transplant, Vol.3, No.11, (November 2003), pp. 1434-9, ISSN 1600-6135.

Fuchinoue, S.; Ishii, Y.; Sawada, T., et al. (2011). The 5-year outcome of ABO-incompatible kidney transplantation with rituximab induction. Transplantation, Vol.91, No.18, (April 2011), pp. 853-7, ISSN 0041-1337.

Gabardi, S.; Martin, S.T.; Roberts, K.L., et al. (2011). Induction immunosuppressive therapies in renal transplantation. Am J Health Syst Pharm, Vol.68, No.3, (February 2011), pp. 211-8, ISSN 1079-2082.

Gaber, A.O.; First, M.R.; Tesi, R.J., et al. (1998). Results of the double-blind, randomized, multicenter, phase III clinical trial of Thymoglobulin versus Atgam in the treatment of acute graft rejection episodes after renal transplantation. Transplantation, Vol.66, No.1, (July 1998), pp. 29-37, ISSN 0041-1337.

Genovese, M.C.; Becker, J.C.; Schiff, M., et al. (2005). Abatacept for rheumatoid arthritis refractory to tumor necrosis alpha inhibition. N Engl J Med, Vol.353, No.11, pp. 1114-23, ISSN 0028-4793.

Genzyme Corporation. (2005).. Thymoglobulin (rabbit antithymocyte globulin) prescribing information. Cambridge, MA; 2005.

Giessing, M.; Budde, K.; Fritsche, L., et al. (2003). 'Old-for-old' cadaveric renal transplantation: surgical findings, perioperative complications and outcome. Eur Urol, Vol.44, No.6, (December 2003), pp. 701-8, ISSN 0302-2838.

Gordon, K.B.; Vaishnaw, A.K.; O'Gorman, J., et al. (2003). Treatment of psoriasis with alefacept: correlation of clinical improvement with reductions of memory T-cell counts. Arch Dermatol, Vol.139, No.12, (December 2003), pp. 1563-70, ISSN 0003987X.

Gourishankar, S.; McDermid, J.C.; Jhangri, G.S., et al. (2004). Herpes zoster infection following solid organ transplantation: incidence, risk factors and outomes in the current immunosuppressive era. Am J Transplant, Vol.4, No.1, (January 2004), pp. 108-15, ISSN 1600-6135.

Grillo-Lopez, A.J.; White, C.A.; Varns, C., et al. (1999). Overview of the clinical development of rituximab: first monoclonal antibody approved for the treatment of lymphoma. Semin Oncol, Vol.26, No.5, (October 1999), pp. 66-73, ISSN 0093-7754.

Grim, S.A.; Pham, T.; Thielke, J., et al. (2007). Infectious complications associated with the use of rituximab for $\mathrm{ABO}$-incompatible and positive cross-match renal transplant recipients. Clin Transplant, Vol.21, No.5, (September 2007), pp. 628-32, ISSN 09020063.

Guttmann, R.D.; Caudrelier, P.; Alberici, G., et al. (1997). Pharmacokinetics, foreign protein immune response, cytokine release, and lymphocyte subsets in patients receiving thymoglobuline and immunosuppression. Transplant Proc, Vol.29, No.7A, pp. 24S6, ISSN 0041-1345.

Haas, M.; Montgomery, R.A.; Segev, D.L., et al. (2007). Subclinical acute antibody-mediated rejection in positive crossmatch renal allografts. Am J Transplant, Vol.7, No.3, (January 2007), pp. 576-85, ISSN 1600-6135. 
Hakim, R.M.; Milford, E.; Himmelfarb, J., et al. (1990). Extracorporeal removal of anti-HLA antibodies in transplant candidates. Am J Kidney Dis, Vol.16, No.5, (November 1990), pp. 423-31, ISSN 0272-6386.

Hale, G.; Waldmann, H.; Friend, P., et al. (1986). Pilot study of CAMPATH-1, a rat monoclonal antibody that fixes human complement, as an immunosuppressant in organ transplantation. Transplantation, Vol.42, No.3, (September 1986), pp. 308-11, ISSN 0041-1337.

Hale, G. (2001). The CD52 antigen and development of the CAMPATH antibodies. Cytotherapy, Vol.3, No.3, (2001), pp. 137-43, ISSN 1465-3249.

Hanaway, M.J.; Woodle, E.S.; Mulgaonkar, S., et al. (2011). Alemtuzumab induction in renal transplantation. N Engl J Med, Vol. 364, No.20, (May 2011), pp. 1909-19, ISSN 00284793.

Hardinger, K.L.; Schnitzler, M.A.; Miller, B., et al. (2004). Five-year follow up of thymoglobulin versus ATGAM induction in adult renal transplantation. Transplantation 2004; 78: 136, ISSN 0041-1337.

Hardinger, K.L. (2006). Rabbit antithymocyte globulin induction therapy in adult renal transplantation. Pharmacotherpay, Vol.26, No.12, (December 2006), pp. 1771-83, ISSN 0277-0008.

Haririan, A.; Nogueira, J.; Kukuruga, D., et al. (2009). Positive cross-match living donor kidney transplantation: Longer-term outcomes. Am J Transplant, Vol.9, No.3, (February 2009), pp. 536-42, ISSN 1600-6135.

Henricsson, A.; Husberg, B., \& Bergentz, S.E. (1977). The mechanism behind the effect of ALG on platelets in vivo. Clin Exp Immunol, Vol.29, No.3, (September 1977), pp. 515-22, ISSN 0009-9104.

Henry, M.L.; Pelletier, R.P.; Elkhammas, E.A., et al. (2001). A randomized prospective trial of OKT3 induction in the current immunosuppression era. Clin Transplant, Vol.15, No.6, (December 2001), pp. 410-4, ISSN 0902-0063.

Hershberger, R.E.; Starling, R.C.; Eisen, H.J., et al. (2005). Daclizumab to prevent rejection after cardiac transplantation. N Engl J Med, Vol.352, No.26, (June 2005), pp. 2705-13, ISSN 0028-4793.

Humar, A.; Ramcharan, T.; Denny, R., et al. (2001). Are wound complications after a kidney transplant more common with modern immunosuppression? Transplantation, Vol.72, No.12, (December 2001), pp. 1920-3, ISSN 0041-1337.

IMTIX-SangStat. (2003). Thymoglobuline (rabbit antithymocyte globulin) prescribing information. Lyon, France; 2003.

Jaffers, G.J.; Fuller, T.C.; Cosimi, A.B., et al. (1986). Monoclonal antibody therapy: antiidiotype and non-anti-idiotype antibodies to OKT3 arising despite intense immunosuppression. Transplantation, Vol.41, No.5, (May 1986), pp. 572-8, ISSN 0041-1337.

Jamil, B.; Nicholls, K.; Becker, G.J., et al. (1999). Impact of acute rejection therapy on infections and malignancies in renal transplant recipients. Transplantation, Vol.68, No.10, (November 1999), pp. 1597-603, ISSN 0041-1337.

Jirasiritham, S.; Khunprakant, R.; Techawathanawanna, N., et al. Treatment of simultaneous acute antibody-mediated rejection and acute cellular rejection with alemtuzumab in kidney transplantation: a case report. Transplant Proc, Vol.42, No.3, (April 2010), pp. 987-9, ISSN 0041-1345. 
Jones, P.T.; Dear, P.H.; Foote, et al. (1986). Replacing the complementarity-determining regions in human antibody with those from a mouse. Nature, Vol.321, No.6069, (May 1986), pp. 522-5, ISSN 0028-0836.

Jordan, S.C.; Toyoda, M., \& Vo, A.A. (2009). Intravenous immunoglobulin a natural regulator of immunity and inflammation. Transplantation, Vol.88, No.1, (July 2009), pp. 1-6, ISSN 0041-1337.

Jordan, S.C.; Toyoda, M.; Kahwaji, J., et al. (2011). Clinical Aspects of Intravenous Immunoglobulin Use in Solid Organ Transplant Recipients. Am J Transplant, Vol.11, No.2, (January 2011), pp. 196-202, ISSN 1600-6135.

Kahan, B.D.; Rajagopalan, P.R. \& Hall, M. (1999). Reduction of the occurrence of acute cellular rejection among renal allograft recipients treated with basiliximab, a chimeric anti-interleukin-2-receptor monoclonal antibody. Transplantation, Vol.67, No.2, pp. 276-84, ISSN 0041-1337.

Kahwaji, J.; Barker, E.; Pepkowitz, S., et al. (2009). Acute hemolysis after high dose IVIG therapy in highly HLA sensitized patients. Clin J Am Soc Nephrol, Vol.4, No.12, (October 2009), pp. 1993-7, ISSN 1555-9041.

Kamar, N.; Milioto, O.; Puissant-Lubrano, B., et al. (2010). Incidence and predictive factors for infectious disease after rituximab therapy in kidney-transplant patients. Am J Transplant, Vol.10, No.1, (July 2009), pp. 89-98, ISSN 1600-6135.

Kamath, S.; Dean, D.; Peddi, V.R., et al. (1997). Efficacy of OKT3 as primary therapy for histologically confirmed acute renal allograft rejection. Transplantation, Vol.64, No.10, (November 1997), pp. 1428-32, ISSN 0041-1337.

Kaplan, B.; Gangemi, A.; Thielke, J., et al. (2007). Successful rescue of refractory severe antibody mediated rejection with splenectomy. Transplantion, Vol.83, No.1, (January 2007), pp. 99-100, ISSN 0041-1337.

Kawai, T.; Cosimi, A.B.; Spitzer, T.R., et al. (2008). HLA-mismatched renal transplantation without maintenance immunosuppression. $N$ Engl J Med, Vol.358, No..4, (January 2008), pp. 353-61, ISSN 0028-4793.

Kazatchkine, M.D. \& Kaveri, S.V. (2001). Immunomodulation of autoimmune and inflammatory disease with intravenous immune globulin. N Engl J Med, Vol.345, No.10, (September 2001), pp. 747-55, ISSN 0028-4793.

Kerr, P.G. \& Atkins, R.C. (1989). The effects of OKT3 therapy on infiltrating lymphocytes in rejecting renal allografts. Transplantation, Vol.48, No.1, (July 1989), pp. 33-6, ISSN 0041-1337.

Kirk, A.D.; Harlan, D.M.; Armstrong, N.N., et al. (1997). CTLA4-Ig and anti-CD40 ligand prevent renal allograft rejection in primates. Proc Natl Acad Sci U S A, Vol.94, No.16, (August 1997), pp. 8789-94, ISSN 0027-8424.

Kirk, A.D.; Hale, D.A.; Mannon, R.B., et al. (2003). Results from a human renal allograft tolerance trial evaluating the humanized CD52-specific monoclonal antibody alemtuzumab (CAMPATH-1H). Transplantation, Vol.76, No.1, (July 2003), pp. 120-9, ISSN 0041-1337.

Kirk, A.D.; Hale, D.A.; Swanson, S.J., et al. (2006). Autoimmune thyroid disease after renal transplantation using depletional induction with alemtuzumab. Am J Transplant, Vol.6, No.5, (May 2006), pp. 1084-5, ISSN 1600-6135. 
Kirkman, R.L.; Shapiro, M.E.; Carpenter, C.B., et al. (1991). A randomized prospective trial of anti-Tac monoclonal antibody in human renal transplantation. Transplantation, Vol.51, No.1, (January 1991), pp. 107-13, ISSN 0041-1337.

Kohler, G. \& Milstein, C. (1975). Continuous cultures of fused cells secreting antibody of predefined specificity. Nature, Vol.256, No.5517, (August 1975), pp. 495-7, ISSN 0028-0836.

Langley, R.G.; Papp, K.; Bissonnette, R., et al. (2010). Safety profile of intravenous and subcutaneous siplizumab, an anti-CD2 monoclonal antibody, for the treatment of plaque psoriasis: results of two randomized, double-blind, placebo-controlled studies. Int J Dermatol, Vol.49, No.7, (July 2010), pp. 818-28, ISSN 0011-9059.

Larrea, C.F.; Cofan, F.; Oppenheimer, F., et al. (2010). Efficacy of eculizumab in the treatment of recurrent atypical hemolytic-uremic syndrome after renal transplantation. Transplantation, Vol.89, No.7, (April 2010), pp. 903-4, ISSN 0041-1337.

Lazarovits, A.I.; Rochon, J.; Banks, L., et al. (1993). Human mouse chimeric CD7 monoclonal antibody for the prophylaxis of kidney transplant rejection. J Immunol, Vol.150, No.11, (June 1993), pp. 5163-74, ISSN 0022-1767.

Lebranchu, Y.; Bridoux, F.; Buchler, M., et al. (2002). Immunoprophylaxis with basiliximab compared with antithymocyte globulin in renal transplant patients receiving MMF-containing triple therapy. Am J Transplant, Vol.2, No.1, pp. 48-56, ISSN 1600-6135.

Lefaucheur, C.; Nochy, D.; Hill, G.S., et al. (2007). Determinants of poor graft outcome in patients with antibody-mediated acute rejection. Am J Transplant, Vol.7, No.4, (April 2007), pp. 832-41, ISSN 1600-6135.

Lefaucheur, C.; Nochy, D.; Andrade, J., et al. (2009). Comparison of combination plasmapheresis/IVIG/Anti-CD20 versus high dose IVIG in the treatment of antibody-mediated rejection. Am J Transplant, Vol.9, No.5, (May 2009), pp. 1099-107, ISSN 1600-6135.

Legendre, C.; Kreis, H.; Bach, J., et al. (1992). Prediction of successful allograft rejection retreatment with OKT3. Transplantation, Vol.53, No.1, (January 1992), pp. 87-90, ISSN 0041-1337.

Lenschow, D.J.; Zeng, Y.; Thistlethwaite, J.R., et al. (1992). Long-term survival of xenogeneic pancreatic islet grafts induced with CTLA4Ig. Science, Vol.257, No.5071, (August 1992), pp. 789-92, ISSN 0036-8075.

Loupy, A.; Suberbielle-Boissel, C.; Hill, G.S., et al. (2009). Outcome of subclinical antibodymediated rejection in kidney transplant recipients with preformed donor-specific antibodies. Am J Transplant, Vol.9, No.11, (September 2009), pp. 2561-70, ISSN 16006135.

Marfo, K.; Lu, A.; Ling, M., et al. (2011). Desensitization protocols and their outcome. Clin J Am Soc Nephrol, Vol.6, No.4, (March 2011), pp. 922-36, ISSN 1555-9041.

Martin, M.A.; Massanari, M.; Nghiem, D.D., et al. (1988). Nosocomial aseptic meningitis associated with administration of OKT3. JAMA, Vol.259, No.13, (April 1988), pp. 2002-5, ISSN 0002-9955.

Meier-Kriesche, H.U.; Ojo, A.O.; Hanson, J.A., \& Kaplan, B. (2001). Exponentially increased risk of infectious death in older renal transplant recipients. Kidney Int, Vol.59, No.4, (April 2001), pp. 1539-43, ISSN 0085-2538. 
Meier-Kriesche, H.U.; Li, S.; Gruessner, R.W., et al. (2006). Immunosuppression: evolution in practice and trends, 1994-2004. Am J Transplant, Vol.6, No.5, (2006), pp. 1111-31, ISSN 1600-6135.

Merion, R.; White, D.J.; Thiru, S., et al. (1984). Cyclosporine: five years experience in cadaveric renal transplantation. $N$ Engl J Med, Vol.310, No.3, (January 1984), pp. 148-54, ISSN 0028-4793.

Morrison, S.L.; Johnson, M.J.; Herzenberg, L.A., et al. (1984). Chimeric human antibody molecules: mouse antigen-binding domains with human constant region domains. Proc Natl Acad Sci U S A, Vol.81, No.21, (November 1984), pp. 6851-5, ISSN 00278424.

Mourad, G.; Garrigue, V.; Squifflet, J.P., et al. (2001). Induction versus noninduction in renal transplant recipients with tacrolimus-based immunosuppression. Transplantation, Vol.72, No.6, (September 2001), pp. 1050-5, ISSN 0041-1337.

Mourad, G.; Rostaing, L.; Legendre, C., et al. (2004). Sequential protocols using basiliximab versus antithymocyte globulins in renal-transplant patients receiving mycophenolate mofetil and steroids. Transplantation, Vol.78, No.4, (August 2004), pp. 584-90, ISSN 0041-1337.

Nashan, B.; Moore, R.; Amlot, P., et al. (1997). Randomized trial of basiliximab versus placebo for control of acute cellular rejection in renal allograft recipients. CHIB201 International Study Group. Lancet, Vol.350, No.9086, (October 1997), pp. 1193-8, ISSN 0140-6736.

Nashan, B.; Light, S.; Hardie, I.R., et al. (1999). Reduction of acute renal allograft rejection by daclizumab. Transplantation, Vol.67, No.1, (January 1999), pp. 110-5, ISSN 00411337.

Niblack, G.; Johnson, K.; Williams, T., et al. (1987). Antibody formation following administration of antilymphocyte serum. Transplant Proc, Vol.19, No.1, (February 1987), pp. 1896-7, ISSN 0041-1345.

Nishida, H.; Ishida, H.; Tanaka, T., et al. (2009). Cytomegalovirus infection following renal transplantation in patients administered low-dose rituximab induction therapy, Transpl Int, Vol.22, No.10, (July 2009), pp. 961-9, ISSN 0934-0874.

Nogid, A. \& Pham, D.Q. (2006). Role of abatacept in the management of rheumatoid arthritis.Clin Ther, Vol.28, No.11, (November 2006), pp. 1764-78, ISSN 0149-2918.

Norman, D.J.; Shield, C.F. III; Barry, J., et al. (1988). Early use of OKT3 monoclonal antibody in renal transplantation to prevent acute rejection. Am J Kidney Dis, Vol.11, No.2, (February 1988), pp. 107-10, ISSN 0272-6386.

Norman, D.J.; Kahana, L.; Stuart, F.P. Jr., et al. (1993). A randomized clinical trial of induction therapy with OKT3 in kidney transplantation. Transplantation, Vol.55, No.1, (January 1993), pp. 44-50, ISSN 0041-1337.

Opelz, G. (1995). Efficacy of rejection prophylaxis with OKT3 in renal transplantation. Collaborative Transplant Study. Transplantation, Vol.60, No.11, (December 1995), pp. 1220-4, ISSN 0041-1337.

Ortho Multicenter Transplant Study Group. (1985). A randomized clinical trial of OKT3 monoclonal antibody for acute rejection of cadaveric renal transplants. $N$ Engl J Med, Vol. 313, No.6, (August 1985), pp. 337-42, ISSN 0028-4793.

Parrott, N.R.; Hammad, A.Q.; Watson, C.J., et al. (2005). Multicenter, randomized study of the effectiveness of basiliximab in avoiding addition of steroids to cyclosporine a 
monotherapy in renal transplant recipients. Transplantation, Vol.79, No.3, (February 2005), pp. 344-8, ISSN 0041-1337.

Pearl, J.P.; Parris, J.; Hale, D.A., et al. (2005). Immunocompetent T-cells with a memory-like phenotype are the dominant cell type following antibody-mediated T-cell depletion. Am J Transplant, Vol.5, No.3, (March 2005), pp. 465-74, ISSN 1600-6135.

Perry, D.K.; Burns, J.M.; Pollinger, H.S., et al. (2009). Proteasome inhibition causes apoptosis of normal human plasma cells preventing alloantibody production. Am J Transplant, Vol.9, No.1, (January 2009), pp. 201-9, ISSN 1600-6135.

Pisani, B.A.; Mullen, G.M.; Malinowska, K., et al. (1999). Plasma- pheresis with intravenous immunoglobulin $\mathrm{G}$ is effective in patients with elevated panel reactive antibody prior to cardiac transplantation. J Heart Lung Transplant, Vol.18, No.7, (July 1999), pp. 701-6, ISSN 1053-2498.

Ponticelli, C.; Rivolta, E.; Tarantino, A., et al. (1987). Treatment of severe rejection of kidney transplant with OKT3.PAN. Transplant Proc, Vol.1, No.1, (February 1987), pp. 19089, ISSN 0041-1345.

Prin Mathieu, C.; Renoult, E.; Kennel De March, A., et al. (1997). Serum anti-rabiit and antihorse IgG, IgA, and IgM in kidney transplant recipients. Nephrol Dial Transplant, Vol.12, No.10, (October 1997), pp. 2133-9, ISSN 0931-0509.

Pruett, T.L.; McGory, R.W.; Wright, F.H., et al. (2009). Safety profile, pharmacokinetics, and pharmacodynamics of siplizumab, a humanized anti-CD2 monoclonal antibody, in renal allograft recipients. Transplant Proc, Vol.41, No.9, (November 2009), pp. 365561, ISSN 0041-1345.

Rosenberg, J.C.; Lekas, N.; Lysz, K., et al. (1975). Effect of antithymocyte globulin and other immune reactants on human platelets. Surgery, Vol.77, No.4, (April 1975), pp. 520-9, ISSN 0039-6060.

Rudich, S.M.; Kaplan, B.; Magee, J.C., et al. (2002). Renal transplantations performed using non-heart-beating organ donors: going back to the future? Transplantation, Vol.74, No.12, (December 2002), pp. 1715-20, ISSN 0041-1337.

San Miguel, J.F.; Schlag, R.; Khuageva, N.K., et al. (2008). Bortezomib plus melphalan and prednisone for initial treatment of multiple myeloma. $N$ Engl J Med, Vol.359, No.9, (August 2008), pp. 906-17, ISSN 0028-4793.

Schaffer, D.; Langone, A.; Nylander, W.A., et al. (2003). A pilot protocol of a calcineurininhibitor free regimen of kidney transplant recipients of marginal donor kidneys or with delayed graft function. Clin Transplant, Vol.17, No.9, (2003), pp. 31-4, ISSN 0902-0063.

Schroeder, T.J.; First, M.R.; Mansour, M.E., et al. (1990). Antimurine antibody formation following OKT3 therapy. Transplantation, Vol.49, No.1, pp. 48-51, ISSN 0041-1337.

Sharma, L.C.; Muirhead, N., \& Lazarovits, A.I. (1997). Human mouse chimeric CD7 monoclonal antibody (SDZCHH380) for the prophylaxis of kidney transplant rejection: analysis beyond 4 years. Transplant Proc, Vol.29, No.1-2, (February 1997), pp. 323-4, ISSN 0041-1345.

Shehata, N.; Palda, V.; Meyer, R., et al. (2010). The use of immunoglobulin therapy for patients undergoing solid organ transplantation: an evidence -based practice guideline. Transf Med Rev, Vol.24, No.1, (January 2010), pp. S7-27, ISSN 08877963. 
Shield, C.F.; Edwards, E.B.; Davies, D.B., et al. (1997). Antilymphocyte induction therapy in cadaver renal transplantation. Transplantation, Vol.63, No.9, (May 1997), pp. 125763 ISSN 0041-1337.

Shoskes, D.A. \& Halloran, P.F. (1996). Delayed graft function in renal transplantation: etiology, management and long-term significance. J Urol, Vol.155, No.6, (June 1996), pp. 1831-40, ISSN 0022-5347.

Singh, A.; Stablein, D., \& Tejani, A. (1997). Risk factors for vascular thrombosis in pediatric renal transplantation: a special report of the North American Pediatric Renal Transplant Cooperative Study. Transplantation, Vol.63, No.9, (May 1997), pp. 12637, ISSN 0041-1337.

Sonnenday, C.J.; Warren, D.S.; Cooper, M., et al. (2004). Plasmapheresis, CMV, hyperimmune globulin, and anti-CD20 allow ABO-incompatible renal transplantation without splenectomy. Am J Transplant, Vol.4, No.8, (August 2004), pp. 1315-22, ISSN 1600-6135.

Spitzer, T.R.; McAfee, S.L.; Dey, B.R., et al. (2003). Nonmyeloablative haploidentical stemcell transplantation using anti-CD2 monoclonal antibody (MEDI-507)-based conditioning for refractory hematologic malignancies. Transplantation, Vol.75, No.10, (May 2003), pp. 1748-51, ISSN 0041-1337.

Squifflet, J.P.; Besse, T.; Malaise, J., et al. (1997). BTI-322 for induction therapy after renal transplantation: a randomized study. Transplant Proc, Vol.29, No.1-2, (February 1997), pp. 317-9, ISSN 0041-1345.

Stratta, P.; Morellini, V.; Musetti, C., et al. (2008). Malignancy after kidney transplantation: results of 400 patients from a single center. Clin Transplant, Vol.22, No.4, (February 2008), pp. 424-7, ISSN 0902-0063.

Svoboda, J.; Kotloff, R., \& Tsai, D.E. (2006). Management of patients with post-transplant lymphoproliferative disorder: the role of rituximab. Transpl Int, Vol.19, No.4, (April 2006), pp. 259-69, ISSN 0934-0874.

Szczech, L.A.; Berlin, J.A.; Aradhye, S., et al. (1997). Effect of anti-lymphocyte induction therapy on renal allograft survival: a meta-analysis. J Am Soc Nephrol, Vol.8, No.11, (November 1997), pp. 1771-7, ISSN 1046-6673.

Tatum, A.H.; Bollinger, R.R., \& Sanfilippo, F. (1984). Rapid serological diagnosis of serum sickness from antilymphocyte globulin therapy using enzyme immunoassay. Transplantation, Vol.38, No.6, (December 1984), pp. 582-6, ISSN 0041-1337.

Tesi, R.J.; Elkhammas, E.A.; Henry, M.L., et al. (1993). OKT3 for primary therapy of the first rejection episode in kidney transplants. Transplantation, Vol.55, No.5, (May 1993), pp. 1023-9, ISSN 0041-1337.

Thistlethwaite, J.R. Jr; Gaber, A.O.; Haag, B.W., et al. (1987). OKT3 treatment of steroidresistant renal allograft rejection. Transplantation, Vol.43, No.2, (February 1987), pp. 176-84, ISSN 0041-1337.

Thistlethwaite, J.R. Jr; Stuart, J.K.; Mayes, J.T., et al. (1988). Complications and monitoring of OKT3 therapy. Am J Kidney Dis, Vol.11, No.2, (February 1988), pp. 112-9, ISSN 02726386.

Tite, J.P.; Sloan, A.; Janeway, C.J. (1986). The role of L3T4 in T cell activation: L3T4 may be both an Ia-binding protein and a receptor that transduces a negative signal. J Mol Cell Immunol, Vol.2, No.4, (1986), pp. 179-90, ISSN 0724-6803. 
Trivedi, H.L.; Terasaki, P.I.; Feroz, A., et al. (2009). Abrogation of anti-HLA antibodies via proteasome inhibition. Transplantation, Vol.87, No.10, (May 2009), pp.1555-61, ISSN 0041-1337.

Turka, L.A.; Linsley, P.S.; Lin, H., et al. (1992). T-cell activation by the CD28 ligand B7 is required for cardiac allograft rejection in vivo. Proc Natl Acad Sci U S A, Vol.89, No.22, (November 1992), pp. 11102-5, ISSN 0027-8424.

Tyden, G.; Genberg, H.; Tollemar, J., et al. (2009). A randomized, double-blind, placebocontrolled, study of single-dose rituximab as induction in renal transplantation. TransplantationI, Vol.87, No.9, (May 2009), pp. 1325-9, ISSN 0041-1337.

Vallhonrat, H.; Williams, W.W.; Cosimi, A.B., et al. (1999). In vivo generation of C4b, Bb, iC3b, and SC5b-9 after OKT3 administration in kidney and lung transplant recipients. Transplantation, Vol.67, No.2, (January 1999), pp. 253-8, ISSN 00411337.

Vigeral, P.; Chkoff, N.; Chatenoud, L., et al. (1986). Prophylactic use of OKT3 monoclonal antibody in cadaveric kidney recipients: utilization of OKT3 as the sole immunosuppressive agent. Transplantation, Vol.41, No.6, (June 1986), pp. 730-3, ISSN 0041-1337.

Vincenti, F.; Lantz, M.; Birnbaum, J., et al. (1997). A phase I trial of humanized antiinterleukin 2 receptor antibody in renal transplantation. Transplantation, Vol.63, No.1, (January 1997), pp. 33-8, ISSN 0041-1337.

Vincenti, F.; Ramos, E.; Brattstrom, C., et al. (2001). Multicenter trial exploring calcineurin inhibitors avoidance in renal transplantation. Transplantation, Vol.71, No.9, (May 2011), pp. 1282-7, ISSN 0041-1337.

Vincenti, F.; Larsen, C.; Durrbach, A., et al. (2005). Costimulation blockade with belatacept in renal transplantation. N Engl J Med, Vol.353, No.8, (August 2005), pp. 770-81, ISSN 0028-4793.

Vincenti, F.; Charpentier, B.; Vanrenterghem, Y., et al. (2010). A phase III study of belatacept-based immunosuppression regimens versus cyclosporine in renal transplant recipients (BENEFIT study). Am J Transplant, Vol.10, No.3, (March 2010), pp. 535-46, ISSN 1600-6135.

Waid, T.H.; Lucas, B.A.; Thompson, J.S., et al. (1992). Treatment of acute cellular rejection with T10B9.1A-31 or OKT3 in renal allograft recipients. Transplantation, Vol.53, No.1, (January 1992), pp. 80-6, ISSN 0041-1337.

Waid, T.H.; Lucas, B.A.; Thompson, J.S, et al. (1997a). Treatment of renal allograft rejection with T10B9.1A-31 or OKT3: Final analysis of a phase 2 clinical trial. Transplantation, Vol.64, No.2, (July 1997), pp. 274-81, ISSN 0041-1337.

Waid, T.H.; Thompson, J.S.; McKeown, J.W., et al. (1997b). Induction immunotherapy in heart transplantation with T10B9.1A-31: a phase I study. J Heart Lung Transplant, Vol.16, No.9, (September 1997), pp. 913-6, ISSN 1053-2498.

Waid, T.H.; Thompson, J.S.; Siemionow, M., et al. (2009). T10B9 monoclonal antibody: a short-acting nonstimulating monoclonal antibody that spares gammadelta T-cells and treats and prevents cellular rejection. Drug Des Devel Ther, Vol.3, (Septemeber 2009), pp. 205-12 ISSN 1177-8881.

Weaver, T.A.; Charafeddine, A.H.; Agarwal, A., et al. (2009). Alefacept promotes costimulation blockade based allograft survival in nonhuman primates. Nat Med, Vol.15, No.7, (July 2009), pp. 746-9, ISSN 1078-8956. 
Webster, A; Pankhurst, T.; Rinaldi, F., et al. (2006). Polyclonal and monoclonal antibodies for treating acute rejection episodes in kidney transplant recipients. Cochrane Database Syst Rev, Vol.19, No.2, (April 2006), pp. CD004756, ISSN 1469-493X.

Wong, J.T.; Eylath, A.A.; Ghobrial, I., et al. (1990). The mechanism of anti-CD3 monoclonal antibodies: mediation of cytolysis by inter-T cell bridging. Transplantation, Vol.50, No.4, (October 1990), pp. 683-9, ISSN 0041-1337. 


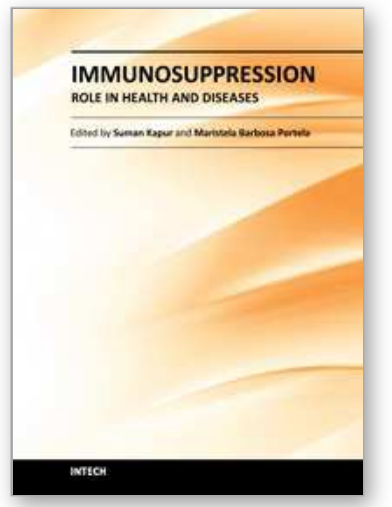

\author{
Immunosuppression - Role in Health and Diseases \\ Edited by Dr. Suman Kapur
}

ISBN 978-953-51-0152-9

Hard cover, 470 pages

Publisher InTech

Published online 24, February, 2012

Published in print edition February, 2012

A need for a book on immunology which primarily focuses on the needs of medical and clinical research students was recognized. This book, "Immunosuppression - Role in Health and Diseases" is relatively short and contains topics relevant to the understanding of human immune system and its role in health and diseases. Immunosuppression involves an act that reduces the activation or efficacy of the immune system. Therapeutic immunosuppression has applications in clinical medicine, ranging from prevention and treatment of organ/bone marrow transplant rejection, management of autoimmune and inflammatory disorders. It brings important developments both in the field of molecular mechanisms involved and active therapeutic approaches employed for immunosuppression in various human disease conditions. There was a need to bring this information together in a single volume, as much of the recent developments are dispersed throughout biomedical literature, largely in specialized journals. This book will serve well the practicing physicians, surgeons and biomedical scientists as it provides an insight into various approaches to immunosuppression and reviews current developments in each area.

\title{
How to reference
}

In order to correctly reference this scholarly work, feel free to copy and paste the following:

Cheguevara Afaneh, Meredith J. Aull, Sandip Kapur and David B. Leeser (2012). Induction Therapy in Renal Transplant Recipients, Immunosuppression - Role in Health and Diseases, Dr. Suman Kapur (Ed.), ISBN: 978953-51-0152-9, InTech, Available from: http://www.intechopen.com/books/immunosuppression-role-in-healthand-diseases/induction-therapy-in-renal-transplant-recipients

\section{INTECH}

open science | open minds

\section{InTech Europe}

University Campus STeP Ri

Slavka Krautzeka 83/A

51000 Rijeka, Croatia

Phone: +385 (51) 770447

Fax: +385 (51) 686166

www.intechopen.com

\section{InTech China}

Unit 405, Office Block, Hotel Equatorial Shanghai

No.65, Yan An Road (West), Shanghai, 200040, China 中国上海市延安西路65号上海国际贵都大饭店办公楼 405 单元

Phone: +86-21-62489820

Fax: +86-21-62489821 
(C) 2012 The Author(s). Licensee IntechOpen. This is an open access article distributed under the terms of the Creative Commons Attribution 3.0 License, which permits unrestricted use, distribution, and reproduction in any medium, provided the original work is properly cited. 